\title{
Paulina Kucińska*
}

\section{Innowacyjne metody kreowania wizerunku pracodawcy}

Streszczenie: w dobie rosnącej konkurencji i dynamicznego postępu technicznego przedsiębiorstwa dążą do zbudowania silnej marki i osiągnięcia przewagi na rynku. Unikatowy wizerunek można zbudować dzięki innowacyjnym rozwiązaniom, które pozwalają zwrócić uwagę otoczenia i zdobyć wartościowych kandydatów. Celem artykułu jest prezentacja innowacyjnych metod kreowania wizerunku pracodawcy oraz ich znaczenia dla funkcjonowania przedsiębiorstwa na rynku pracy. Zagadnienia te zostały przedstawione na przykładzie firm światowych, polskich oraz na podstawie badań własnych.

Słowa kluczowe: wizerunek pracodawcy, innowacyjność, marka.

\section{Wstęp}

Obecnie można zaobserwować rosnące zainteresowanie metodyką kreowania wizerunku pracodawcy i dążenie firm do unowocześnienia stosowanych przez nie rozwiązań w tym obszarze. Przyczyniły się do tego zmiany na rynku i w otoczeniu przedsiębiorstw.

Budowanie wizerunku marki pracodawcy określa się najprościej jako udoskonalanie powszechnie znanych metod rekrutacji o narzędzia marketingowe. W dobie zaostrzającej się konkurencji zauważono jednak, że jego rola nie ogranicza się tylko do wspierania procesu rekrutacji. Ważna jest również dbałość o to, żeby pracownicy pozostali w organizacji, byli zmotywowani i angażowali się w jej działalność. Przykłady przytoczone w artykule mają zwrócić uwagę na rolę właściwego doboru i formę innowacyjnych metod employer brandingu (EB) w postrzeganiu przedsiębiorstwa $\mathrm{w}$ otoczeniu rynkowym. Zastosowane rozwiązania zostaną przedstawione na przykładzie firm zagranicznych i polskich.

Do badań własnych wybrano dwie łódzkie firmy: Grupę Kapitałową Powszechnego Zakładu Ubezpieczeń SA (Grupę PZU SA) oraz mBank.

* Uniwersytet Łódzki, Wydział Zarządzania, studia licencjackie. 
Celem badania było pokazanie innowacyjnego podejścia tych firm do kreowania wizerunku pracodawcy, porównanie używanych przez nie metod i narzędzi oraz przedstawienie korzyści z nich wynikających.

\section{Rola employer brandingu we wspólczesnym zarządzaniu}

Analizując etymologię EB, należy zwrócić uwagę na jego związek z następującymi pojęciami: marka (brand), budowanie marki (branding) i wizerunek (image) [Wojtaszczyk, 2012: 78]. Tym samym zarządzanie marką pracodawcy kojarzy się z jej budowaniem przez organizację i jej promowaniem przez pracowników. Przez wiele lat działalność marketingowa skupiała się na marce, czyli specyficznych cechach danego produktu, odróżniających towary jednej firmy od konkurencji. W ostatnim czasie marka zaczęła być postrzegana jako doświadczenia umysłu oraz emocji konsumentów i klientów związane z określonym produktem [de Chernatony, 2003: 9]. Aby uzyskać wysoką pozycję na rynku, menedżerowie stawiają sobie za cel wypromowanie marki, tak żeby zyskała przewagę nad konkurencją.

Techniki marketingowe stosowane pierwotnie do zdobycia wierności klienta wykorzystuje się obecnie do zbudowania relacji z pracownikiem. Najpierw jednak musi zostać zdefiniowana propozycja wartości złożona przez pracodawcę (EVB - employee value proposition) [Wojtaszczyk, 2012: 79], przedstawiająca ofertę i korzystne warunki zatrudnienia.

Wartość pracodawcy tworzona jest na podstawie dwóch rodzajów atrybutów. Pierwszy z nich obejmuje cechy subiektywne i abstrakcyjne, takie jak: reputacja, innowacja i prestiż organizacji. Drugi wyznacznik to cechy obiektywne i fizyczne dotyczące pracowników, tj. nagrody i możliwości rozwoju w toku pracy. Propozycja wartości musi być zgodna z tożsamością organizacji (jej rolą na podstawie poglądów zewnętrznych i wewnętrznych podmiotów, mających wpływ na działanie firmy) oraz autentyczna, tak żeby w jak największym stopniu sprostać wymaganiom pracowników, szczególnie podczas implementacji nowych wartości.

Głównym celem EB jest wyróżnienie się pracodawcy na rynku pracy dzięki uzyskaniu miana pracodawcy z wyboru (employer of choice) [Hillebrandt, 2013: 25] i tym samym zdobycie jak najbardziej wartościowych pracowników. Ustalenie propozycji wartości oferowanych przez pracodawcę pomaga $\mathrm{w}$ osiągnięciu wcześniej założonych celów, procesie pozycjonowania organizacji na rynku i efektywnej komunikacji z interesariuszami. 
Ze względu na różnorodność definicji EB niektórzy pracodawcy traktują ten proces jako zastosowanie ulepszonych metod rekrutacji lub - w bardziej szerokim ujęciu - jako kontrakt psychologiczny [KantowiczGdańska, 2009: 57] między przełożonym a pracownikiem. Pracodawca składa ofertę pracy, opartą na kulturze organizacyjnej firmy, jej celach, wizji oraz szacunku i zaufaniu wobec zatrudnionego, natomiast pracownik odpowiada na złożoną ofertę zaangażowaniem, wiernością wobec marki oraz wysiłkiem włożonym w jej budowanie i udoskonalanie.

Teorię kontraktu psychologicznego wykorzystuje model amerykańskich badaczy: Backhaus i Tikoo [Backhaus, Tikoo, 2004: 502-503]. Według nich proces tworzenia tożsamości pracodawcy powinien składać się z trzech etapów. Na początku organizacja tworzy własną markę, która jest równoznaczna z przekazaniem komunikatu, co firma może zaproponować pracownikom. Następnie ta marka zostaje skierowana do kandydatów, agencji specjalizujących się w rekrutacji oraz pozostałych odbiorców rynku pracy, żeby przyciągnąć jak najlepszych pracowników. Tym samym firma rozwija marketing zewnętrzny. W celu osiągnięcia oczekiwanego efektu, czyli zdobycia wartościowej kadry, w końcowej fazie organizacja musi zadbać o aktualnie posiadane zasoby ludzkie, czyli udoskonalić marketing wewnętrzny.

Inaczej podejście do marki pracodawcy opisuje Martin [Martin, 2008: 18-19]. Opierając się na tożsamości organizacyjnej i korporacyjnej, podkreśla on fakt budowania wizerunku pracodawcy jako stwarzającego dobre warunki pracy. Za podstawę EB uznaje się pakiet korzyści oferowanych przez pracodawcę, kreujący wizerunek firmy i przekazany jako komunikat wartości pracownikom i potencjalnym kandydatom. Marka pracodawcy jest w tym wypadku atrybutem symbolicznym, mającym zwiększyć atrakcyjność pracodawcy na rynku zewnętrznym oraz pogłębić poczucie przywiązania i utożsamiania się obecnych pracowników z przedstawioną marką.

\section{Metody employer brandingu w firmach polskich i zagranicznych}

W porównaniu z innymi krajami europejskimi w Polsce metodyka EB nie jest wystarczająco ugruntowana. Wciąż brakuje specjalistów wykształconych w tej dziedzinie. Niemniej jednak zyskuje na znaczeniu, biorąc pod uwagę wysiłki podejmowane przez pracodawców w celu obserwowania i stosowania zagranicznych rozwiązań. Wynika to naturalnie $\mathrm{z}$ chęci zbudowania silnej marki i zdobycia przewagi na rynku. $\mathrm{Z}$ raportu 
HRM Institute z 2015 r. dotyczącego EB płynie wniosek, że pracodawcy traktują rozwój innowacyjności firmy jako pożądaną inwestycję we własną markę [HRM Institute, 2015: 10]. Aby lepiej pozycjonować własną markę i tym samym zdobyć wartościowych kandydatów do pracy, pracodawcy decydują się na różne inwestycje wizerunkowe.

Przykładem działan EB podjętych w ramach mediów społecznościowych może być kampania rekrutacyjna firmy Fenomem. Akcja odbywała się na Snapchacie, ponieważ jej celem było zatrudnienie kandydatów korzystających aktywnie z social media i rozumiejących ich rolę w marketingu firmy. Kampania opierała się na wykorzystaniu snapkodów, które zostały umieszczone na plakatach rozwieszonych na warszawskich słupach. Snapkody odsyłały zainteresowanych użytkowników na profil firmy, na którym uczestnicy mieli za zadanie opracować za pomocą Snapchata kreatywną akcję dla klienta. Na Snapchacie można było także podejrzeć, jak wygląda praca w firmie i jak kształtują się relacje między pracownikami. Twórcy kampanii udowodnili, że można odnieść sukces z mniejszym budżetem, zdobywając jednocześnie odpowiednich kandydatów, specjalizujących się w danej dziedzinie [Rzepka, 2015: 21-23].

Kandydaci z wiedzą i doświadczeniem w określonym zawodzie są szczególnie poszukiwani przez pracodawców. Zdobycie takiego kandydata nie zawsze jest prostym zadaniem, ponieważ osoby te przeważnie mają już dobrą pracę i przez to nie wykazują się aktywnością na rynku pracy. Firmy rekrutacyjne zastanawiają się więc, jak dotrzeć do takich wartościowych kandydatów. Innowacyjną formą rekrutacji zyskującą obecnie na popularności jest scouting [Arndt, 2014]. Polega on na tym, że rekruter stara się znaleźć określonego kandydata w miejscu, w którym można go bezpośrednio spotkać. Scoutingiem posłużył się Volkswagen, któremu zależało na znalezieniu mechaników do jednego z niemieckich zakładów. Rekruterzy postanowili spotkać się z kandydatami bezpośrednio w ich miejscu pracy. Oddając do warsztatu uszkodzone auto, mogli od razu sprawdzić kompetencje kandydatów. Pracownicy warsztatu mieli naprawić uszkodzony samochód, nie wiedząc, że ich umiejętności są oceniane. Ogłoszenie rekrutacyjne było umieszczone najczęściej pod maską samochodu.

Gdy organizacji uda się zachęcić profesjonalistę do przyjęcia oferowanego pakietu korzyści, pozostaje jeszcze wprowadzenie go do środowiska organizacyjnego. Pierwsze dni w nowej pracy bywają dla nowego członka kadry dość stresujące, dlatego też firmy powinny kłaść nacisk na właściwie przeprowadzony proces adaptacji nowego pracownika. Coraz częściej wykorzystuje się do tego celu specjalnie opracowany podręcznik (znany na Zachodzie jako handbook) [Pawłowski, 2015: 34], 
w którym nowy pracownik może znaleźć podstawowe informacje o środowisku i zasadach panujących w firmie. Z tego rozwiązania postanowiła również skorzystać firma IT, eEngine Software House, tworząc Podrecznik Dev Knighta [Pawłowski, 2015: 33]. Organizacja zmodyfikowała tradycyjny układ podręcznika, wzorując się na Valve - amerykańskiej firmie specjalizującej się w produkcji gier komputerowych. Podręcznik Valve przedstawiał atmosferę w firmie jako przyjazną i pozbawioną stresu. Zrezygnowano z książkowego schematu poradnika i wprowadzono słowniczek dla nowego pracownika z wykorzystaniem specyficznego slangu organizacji [Valve Corporation, 2012]. Miało to skrócić dystans między nowym pracownikiem a resztą zespołu i pokazać prawdziwą atmosferę w pracy.

Kolejnym przykładem innowacyjnej kampanii rekrutacyjnej jest akcja „Poczuj miętę do Capgemini” [Capgemini.com]. Aby zostać zauważonym na rynku pracy przez szeroką grupę docelową, firma Capgemini postanowiła wykorzystać w niecodzienny sposób znany frazeologizm „czuć miętę” zarówno w sposób metaforyczny, jak i dosłowny. Na początku firmie zależało na zapoznaniu z pomysłem obecnych pracowników i zaangażowaniu ich do współtworzenia marki pracodawcy. W tym celu w porze nocnej, przed rozpoczęciem nowego tygodnia pracy, na terenie biura umieszczono urządzenia rozpylające miętowy aromat, a w kuchni pracownicy mieli do dyspozycji krzaki mięty. Osoby zatrudnione w Capgemini zostały również zaproszone do wzięcia udziału w konkursie na stworzenie hasła promującego kampanię. Nagrodzono m.in. hasła: Would you mint upgrading your career?, Będzie mięta między nami czy Wypij miętę. Poczuj smak. Obudź myśli. Podbij świat [Mikulska, 2015: 33-35]. W konkursie wyróżniono także zdjęcia z motywem mięty w zależności od wytyczonych kategorii, a nagrodzone prace zostały opublikowane na profilu firmy. Pracownicy bardzo chętnie włączyli się w działania, pokazując tym samym swoje zainteresowanie i chęć wkładu w sukces przedsiębiorstwa.

\section{Innowacyjność w kreowaniu wizerunku pracodawcy: PZU SA i mBank}

Na tle ogólnych rozważań dotyczących innowacyjnych metod kreowania wizerunku pracodawcy oraz ww. przykładów firm przodujących $\mathrm{w}$ tej dziedzinie warto przedstawić informacje o działalności EB w dwóch nowocześnie zarządzanych firmach na terenie Łodzi: Grupie Kapitałowej Powszechnego Zakładu Ubezpieczeń SA (Grupie PZU SA) 
oraz mBanku. Aby zaprezentować podejście tych firm do innowacyjności w kreowaniu wizerunku pracodawcy, autorka przeprowadziła badania własne w formie wywiadu z przedstawicielami firm.

Dla PZU i mBanku bodźcem do zastosowania innowacyjnych metod EB były rosnące oczekiwania przyszłych pracowników i pakiet korzyści proponowany przez konkurencję. Obie firmy dążą do stworzenia spójnego, pozytywnego wizerunku, który nie tylko przyciągnie wartościowych, ambitnych i zmotywowanych kandydatów do pracy i stażystów, ale również pozwoli na ich utrzymanie w firmie przez dłuższy czas. Konieczne jest też poszukiwanie nowych rozwiązań, umożliwiających wyróżnienie się na tle konkurencji.

Przykładem jest akcja „Zasmakuj kariery w mBanku”, nawiązująca do kulinariów. Grupą docelową byli studenci rozpoczynający karierę w trakcie studiów w formie stażu. Jako podstawowe narzędzie kampanii wykorzystano stronę informacyjną BankoweTalenty.pl. Znalazły się na niej najważniejsze informacje, oprócz tego kandydat mógł dopasować program stażowy do swoich mocnych stron na podstawie gry autoselekcyjnej. mBank połączył tradycyjne działania online (informacje w mediach społecznościowych i na portalach pracy w postaci ofert pracy) z grywalizacją i bezpośrednim spotkaniem z kandydatami. Podczas spotkań o nieformalnym charakterze m.in. przy foodtrucku oferującym burgery dla łódzkich studentów i podczas wspólnego gotowania łatwiej było nawiązać kontakt. W efekcie rozmowa o np. rekrutacji i przebiegu stażu przebiegała bardziej naturalnie.

W działalności marketingowej PZU innowacyjne działania EB stały się widoczne od 2013 r. Zapoczątkował je nowatorski spot, w którym kandydatka do pracy miała odgadnąć myśli kury. Podczas kolejnych kampanii położono nacisk na kompetencje pracownicze. Zaprezentowano cechy pozwalające na wyróżnienie się podczas rozmowy rekrutacyjnej, a w trakcie obecnej kampanii określanej jako \#najlepszastrona skupiono się na poznaniu oczekiwań kandydatów odnośnie do procesu rekrutacji. Aktualny spot przedstawia niestandardowe zakończenie rozmowy kwalifikacyjnej, podczas której kandydatka do pracy chwali profesjonalizm osoby rekrutującej, ale sugeruje również, że rekruter powinien zadać jej konkretne pytanie, pozwalające na pokazanie jej swojej najlepszej cechy. Miało to zachęcić członków grupy docelowej do interakcji i przedstawiania własnych propozycji pytań na rozmowie rekrutacyjnej, dzięki którym mogliby pokazać swoje najlepsze cechy i kompetencje.

Firmy stosują raczej własne pomysły na innowacyjne rozwiązania i konsultują je z firmami zewnętrznymi specjalizującymi się w kwestiach marketingowych. W działaniach obu przedsiębiorstw widać jednak 
wpływy metod znanych za granicą: grywalizacji (gra autoselekcyjna na stronie mBanku; gra na stronie PZU - PrzyciagamyNajlepszych.pl) i story telling (wspólne spotkania kulinarne i robienie własnej pizzy). Można zatem zauważyć, że firmy zapożyczają, może czasem nieświadomie, rodzaj innowacji, ale jej forma jest dopasowana do aktualnie przeprowadzanej kampanii.

Badanie dotyczyło również stosowanego przez firmy brandingu wewnętrznego. W mBanku organizowane są szkolenia dla pracowników na podstawie celów biznesowych wyznaczonych dla danego departamentu i kompetencji jego członków. Na terenie firmy cyklicznie odbywają się różne konkursy. Ostatnio przeprowadzono konkurs, w którym pracownicy mogli się nawzajem nominować w różnych kategoriach (np. menedżer, współpracownik, zespół projektowy). Laureaci pojechali w nagrodę na dwutygodniowy wyjazd do Japonii, podczas którego mieli okazję nie tylko zwiedzić Kraj Kwitnącej Wiśni, ale również poszerzyć swoją wiedzę merytoryczną. Podczas spotkania biznesowego z zarządem firmy Toyota dyskutowano m.in. o znaczeniu klienta dla przedsiębiorstwa. Ponadto pracownicy mBanku aktywnie współpracują z Uniwersytetem Łódzkim nie tylko podczas targów pracy, lecz także w ramach kierunku bankowość i finanse cyfrowe na Wydziale Ekonomiczno-Socjologicznym. Wspólnie z wykładowcami przygotowali plan studiów w oparciu o kluczowe kompetencje w dziedzinie bankowości i wymagania pracodawców. Oprócz tego pracownicy dzielą się własnym doświadczeniem oraz wiedzą w ramach zajęć prowadzonych na tym kierunku studiów.

PZU również stosuje branding wewnętrzny. Pracownicy jako ambasadorzy firmy biorą udział w eventach organizowanych na uczelniach i w miejscach publicznych oraz w targach pracy. W myśl kampanii \#najlepszastrona PZU stara się zbierać informacje na temat potrzeb szkoleniowych swoich pracowników i na tej podstawie organizuje szkolenia nie tylko z umiejętności adekwatnych do pracy w danym dziale, ale również z umiejętności miękkich. Przykładowo pracownikom działu IT oferowane są ścieżki rozwojowe, które zawierają informację o dostępnych szkoleniach w zależności od zajmowanego stanowiska. Natomiast w dziale sprzedaży odbywają się warsztaty rozwojowo-szkoleniowe, na które składają się centrum rozwoju (Development Center), ocena 360 stopni i coaching. Ponadto pracownicy mogą otrzymać dofinansowanie do studiów podyplomowych i kursów językowych oraz inne benefity pozapłacowe.

Obie firmy wyróżniają się w obszarze EB, a działania podjęte w celu stworzenia wizerunku atrakcyjnego pracodawcy przyniosły pożądane efekty. Firmy zostały uhonorowane nagrodami za przeprowadzone kam- 
panie, zaobserwowały również większe zainteresowanie swoją działalnością. mBank zdobył tytuł Solidnego Pracodawcy roku 2014, nagrodę EB Stars za zeszłoroczną kampanię „Bankowe Talenty” w kategorii „Najlepsza kampania Employer Branding” oraz wyróżnienie za najlepszą stronę kariery. PZU także zostało wyróżnione podczas EB Stars 2015 (wyróżnienie w kategorii „Najlepsza kampania Employer Branding”, nagroda za najlepsze wykorzystanie social media oraz najlepsze wydarzenie offline). Obserwuje się również awans obydwu firm w studenckim rankingu „Pracodawca Roku” (AIESEC Polska) oraz rankingu „Idealny Pracodawca" (Universum) [Różańska, 2016].

Podsumowując przeprowadzone badanie: mBank i PZU budują swój wizerunek profesjonalnie na podstawie relacji z pracownikiem, preferencji klientów i partnerów biznesowych. Firmy zwracają uwagę na otoczenie rynkowe i starają się dostosować do zachodzących zmian. Swoje kampanie wizerunkowo-rekrutacyjne przygotowują z uwzględnieniem nowinek technologicznych i aktualnych potrzeb grup docelowych, korzystając ze wsparcia firm marketingowych. Dzięki temu przeprowadzane akcje są dopracowane pod każdym względem i odnoszą sukcesy.

\section{Zakończenie}

Obecna sytuacja na rynku pracy i rosnąca konkurencja wymagają od przedsiębiorstw świadomego kreowania własnej marki, wzbudzającej zainteresowanie, a przede wszystkim zaufanie odbiorcy. Przedsiębiorstwa chcące zdobyć wysoką pozycję na rynku powinny być zatem przygotowane na poszukiwanie i wprowadzanie nowych, nieszablonowych rozwiązań, które przyczynią się do wyróżnienia pracodawcy na rynku pracy, uzyskania miana ,pracodawcy z wyboru” i tym samym zdobycia jak najbardziej wartościowych pracowników. Coraz częściej organizacja kreuje zewnętrzny obraz, wykorzystując zasięg internetowych kanałów komunikacyjnych typu social media i popularnych aplikacji, głównie Twittera, Facebooka i Snapchata. Strony informacyjne przedsiębiorstwa dbającego o innowacyjny branding często uzupełniane są o elementy grywalizacji. Zastosowanie nowoczesnych narzędzi kształtowania wizerunku firmy jest szczególnie widoczne podczas wyboru metod komunikacji w kontakcie z przedstawicielami pokolenia Z, którzy są przyzwyczajeni do komunikacji online. Jednak nawet w tym przypadku klasyczne metody kreowania wizerunku pracodawcy, takie jak targi pracy czy wykłady, również są przydatne w przekazywaniu wiedzy merytorycznej i nadal praktykowane. 


\section{BIBLIOGRAFIA}

Arndt A. (2014), Nowe formy rekrutacji, http://blog.goldenline.pl/2014/03/03/noweformy-rekrutacji/ (dostęp: 14.10.2016).

Backhaus K., Tikoo S. (2004), Conceptualizing and researching employer branding, „Career Development International”, vol. 9, no. 4/5.

Bankowe Talenty, http://bankowetalenty.pl/ (dostęp: 14.10.2016).

Capgemini.com, https://www.pl.capgemini.com/poczuj-miete (dostęp: 14.10.2016).

de Chernatony L. (2003), Marka. Wizja i tworzenie marki, Gdańskie Wydawnictwo Psychologiczne, Gdańsk.

Hillebrandt I. (2013), Dimensions of Employer Brands. Bamberg: University of Bamberg.

Kantowicz-Gdańska M. (2009), Employer branding - kwestie definicji i modelu, „Zarządzanie Zasobami Ludzkimi”, nr 6 (71).

Martin G. (2008), Employer branding - time for some long and 'hard' reflections?, [w:] Humpage S. (red.), Research insight: employer branding. The latest fad or the future of HR?, Chartered Institute of Personnel and Development, London.

Mikulska A. (2015). Będzie mięta, „Magazyn Employer Branding”, 4 (11), http://mjcc.pl/ magazyn11/ (dostęp: 14.10.2016).

Pawłowski M. (2015). Jak zostać Dev Knightem — onboarding z podręcznika, „Magazyn Employer Branding”, nr 3 (10), http://mjcc.pl/magazyn10/ (dostęp: 14.10.2016).

Przyciągamy najlepszych 3.0, http://www.przyciagamynajlepszych.pl/ (dostęp: 14.10.2016).

HRM Institute (2015), Raport. Employer Branding w Polsce 2015. Strategie. Narzędzia. Trendy. Wyzwania, http://hrminstitute.pl/dane/raporty/HRMI_raport_EB_2015.pdf (dostęp: 14.10.2016).

Różańska G. (2016), Jak skusić studentów smakiem kariery? O kampanii Bankowe Talenty 2015, http://blog.goldenline.p1/2016/02/22/jak-skusic-studentow-smakiem-kariery-o-kampanii-bankowe-talenty-2015/ (dostęp: 14.10.2016).

Rzepka I. (2015), Rekrutacja, która stata się kampanią reklamowa firmy, „Magazyn Employer Branding”, nr 4 (11), http://mjcc.pl/magazyn11/ (dostęp: 14.10.2016).

Valve Corporation (2012), Handbook for new employees, Bellevue, Washington, USA, http://www.valvesoftware.com/company/Valve_Handbook_LowRes.pdf (dostęp: 14.10.2016).

Wojtaszczyk K. (2012). Employer branding, czyli zarzadzanie marka pracodawcy. Uwarunkowania, procesy, pomiar, Wydawnictwo Uniwersytetu Łódzkiego, Łódź.

\section{INNOVATIVE METHODS OF EMPLOYER BRANDING}

\section{SUMMARY}

Due to increasing competition on the market and dynamic technological progress, the enterprises want to build a strong brand and achieve a competitive advantage. The unique image can be built with innovative solutions that allow to pay attention to the company and gain valuable candidates for work. The aim of the article is to present innovative methods of employer branding and their importance for the functioning of the company on the market. The above mentioned aspects are presented later in this article on the example of different companies in the world, in Poland and also based on the own research.

Keywords: employer branding, innovation, brand. 